\title{
Herbal Mosquito Repellent Liposomal Formulations: A Mini Review
}

\author{
Hemanga Hazarika' ${ }^{1 *}$, Harshita Krishnatreyya ${ }^{2}$, Moksood Ahmed Laskar ${ }^{3}$, Pal Gogoi ${ }^{3}$, Kamaruz Zaman ${ }^{1}$ and $^{-}$ \\ Pronobesh Chattopadhyay ${ }^{2}$
}

${ }^{1}$ Department of Pharmaceutical Science, Dibrugarh University, Assam, India

${ }^{2}$ Division of Pharmaceutical Technology, Defence Research Laboratory, India

${ }^{3}$ Division of Medical Entomology, Defence Research Laboratory, India

Received Date: February 12, 2018; Published Date: February 23, 2018

*Corresponding author: Hemanga Hazarika, Department of Pharmaceutical Science, Dibrugarh University, NH-37, Rajapeta, Dibrugarh, Assam, India, E mail: hemanga14@gmail.com

\begin{abstract}
Mosquito-borne diseases including chikungunya, dengue, filariasis, malaria, and various forms of encephalitis impose enormous menace to human as well as animals. Mosquito repellent is an effective tool for minimize vector borne disease which prevents man-vector contact. Herbal repellents are cost effective, easily available and low toxic as compared to synthetic repellents. Liposome can protect the active repellent moiety from deterioration and give longer effect.
\end{abstract}

Keywords : Mosquito repellents; Herbal; Liposome.

\section{Introduction}

Mosquito repellents: Personal protection measures are the first line protection against mosquito bites. In the protection against arthropods repellent play important role, because they can be used anywhere and anytime. They prevents the vector borne disease incidence by reducing man-vector contact [1]. Possible topical repellent formulations include liquid forms (emulsions, micelles, liquid solutions etc.), semi-liquid forms (gels, liposomes etc.), and solid forms (microcapsules or microcomposites) [2]. Today's mosquito control approaches have been almost completely based on synthetic moieties. The extensive use of synthetic moieties has resulted in ecohazards and also develops resistance in major vector species of mosquitoes [3]. The gold standard mosquito repellent $\mathrm{N}$, $\mathrm{N}$-diethyl toluamide (DEET) provides long-lasting protection against a wide variety of mosquito species [4]. But human toxicity has been reported against DEET. The concentrated formulations dissolve plastic and it is irritating to mucous membranes. It may be unsafe for children possibly causes encephalopathy. Toxicological interaction between DEET and Ach esterase -blocking drug pyridostigmine was suggested as a cause of Gulf war syndrome. Anopheles mosquitoes are generally repelled for shorter time (1-2 h) than either Aedes or Culex [5,6].
Widely used mosquito repellent active moiety in commercial products like $\mathrm{N}, \mathrm{N}$-diethyl phenyl acetamide (DEPA) is also have distinct odor and it also melts plastics, though it is cheap and having broad spectrum of repellency against hematophagus insects. IR3535 fails at low concentration though it is safe and having long evaluation records [6]. Therefore, the development of alternative, environmentally friendly, safe and sustainable approaches for mosquito control with the use of herbal products gaining greater importance with mower bioaccumulation and lower toxicity to non-target animals [7]. Plant based essential oils have received much attention plant based repellents that reduce vector borne disease have the advantage that they are economic and environmentally safe [8]. Essential oils are composed of highly volatile substances having major and minor constituents which have repellent activity against mosquitoes [9-14].

\section{Liposomes}

Salafsky et al. [14], DEET incorporated into liposomes (LIPODEET) for the prevention of schistosomiasis. LIPODEET was found to belonger-acting, minimally absorbed through the skin and loss due to washing off was limited and effective against 
schistosomiasis. Plant based essential oils have a high content of terpenes and sesquiterpenes, in the presence of oxygen from the air they are capable of undergoing undesirable deterioration reactions [10]. In addition, oils can present low solubility in aqueous media, limiting their pharmaceutical applications. This problem can be overcome by producing liposomal formulations, entrapping the oil drops in a lipid barrier [2].

Alec D. Bangham studied on phospholipids and blood clotting and first produced liposomes in 1961 in England. He observed that, for phospholipid moieties, one end of each molecule is water soluble while the opposite end is water insoluble [11]. For this nature, phospholipid immediately forms a sphere shape while combined with water. For the active ingredients which are water soluble, added to the water and trapped inside the aggregation of the hydrophobic ends. For fat-soluble medications, they are incorporated into the phospholipid layer. Liposomes improve clinical efficacy, drug delivery, drug loading and offers sustained release of active moieties which are advantageous over traditional dosage form [12,13]. In 1995 Liposomes were approved for clinical use as the first nanoscale drug. Since then, with significant clinical implications liposome-based delivery systems has brought about remarkable developments like: covalent lipid-drug complexes for improved drug plasma membrane crossing and targeting to specific organelles; elastic liposomes for topical, oral and transdermal delivery; longcirculating liposomes; nebulized liposomes; stimuli-responsive liposomes [14,15].

\section{Conclusion}

Herbal repellent reduce the toxicity and side effects as compared to the synthetics. Pharmaceutical industry, researchers have raised concern about the mosquito repellent products using herbal ingredients. The use of a lipid-based formulation system such as liposomes should yield a better impact on the stability, as well as the release of the active ingredient i.e. essential oil.

\section{References}

1. Uniyal A, Sachin Tikar N, Om Agrawal P, Shakti Shukla V, Devanathan Sukumaran et al. (2017) Formulation and Evaluation of Vanishing Cream Based Mosquito Repellent Against Aedes aegypti. Life Science and Environment 1(1): 15-20.
2. Brunner G (2001) Gas Extraction, Berlin: Springer, 1994 Valenti D, De Logu A, Loy G, Sinico C, Bonsignore L, Cottiglia F, Garau D, Fadda AM.

3. Enayati A, Garner P, Hemingway J (2007) Electronic mosquito repellents for preventing mosquito bites and malaria infection. The Cochrane Library 4: 5.

4. Briassoulis G, Narlioglou M, Hatzis T (2001) Toxic encephalopathy associated with use of DEET insect repellents: a case analysis of its toxicity in children. Hum Exp Toxicol 20(1): 8-14.

5. Abdel Rahman A, Shetty AK, Abou Donia MB (2001) Subchronic dermal application of $\mathrm{N}, \mathrm{N}$-diethyl m-toluamide (DEET) and permethrin to adult rats, alone or in combination, causes diffuse neuronal cell death and cytoskeletal abnormalities in the cerebral cortex and the hippocampus, and Purkinje neuron loss in the cerebellum. Exp Neurol 172: $153-171$

6. Strickman D, Frances SP, Debboun M (2009) Prevention of bug bites, stings, and disease. Oxford University Press, India.

7. Benner JP (1993) Pesticidal compounds from higher plants. Pestic Sci 39: $95-102$.

8. Amer A, Melhorn H (2006) Repellency effect of forty one essential oils against Aedes, Anopheles, and Culex mosquitoes. Parasitology Research 99(4): 478-490.

9. Enayati A, Garner P, Hemingway J (2007) Electronic mosquito repellents for preventing mosquito bites and malaria infection. The Cochrane Library 4: 5.

10. Valenti D, De Logu A, Loy G, Sinico C, Bonsignore L, et al. (2001) Liposome-incorporation Santolina insularis essential oil: Preparation, characterization and in vitro antiviral activity. J Lip Res 11(1):73-90.

11. Sezer AD, Bas AL, and Akbugaet J (2004) Encapsulation of Enrofloxacin in Liposomes I: preparation and in vitro characterization of LUV J Lipo Res 14(1-2): 77-86.

12. Law SL, Huang KJ, Chou VHY (2003) Stability of Desmopressin loaded in Liposomes; J Lipo Res 13(3-4): 269-277.

13. Kamra M, Diwan, A, Sardana S (2017) Topical liposomal gel: a review. International journal of pharmaceutical sciences and research 8(6): 2408-2414.

14.Zylberberg C, Matosevic S (2016) Pharmaceutical liposomal drug delivery: a review of new delivery systems and a look at the regulatory landscape. Drug delivery 23(9): 3319-3329.

15. Salafsky B, Ramaswamy, K, He YX, Li J, Shibuya T (1999) Development and evaluation of LIPODEET, a new long-acting formulation of $\mathrm{N}, \mathrm{N}$-diethyl-m-toluamide (DEET) for the prevention of schistosomiasis. The American journal of tropical medicine and hygiene 61(5): 743-750.

\section{Your next submission with Juniper Publishers} will reach you the below assets

- Quality Editorial service

- Swift Peer Review

- Reprints availability

- E-prints Service

- Manuscript Podcast for convenient understanding

- Global attainment for your research

- Manuscript accessibility in different formats

( Pdf, E-pub, Full Text, Audio)

- Unceasing customer service

Track the below URL for one-step submission

https://juniperpublishers.com/online-submission.php 